\title{
PENTINGNYA PERAWAT MENERAPKAN BUDAYA KESELAMATAN PASIEN DI RUMAH SAKIT
}

\author{
Wanda Miftah Fatihah \\ Email : wandamiftah22@gmail.com
}

\begin{abstract}
ABSTRAK
Masalah etik di rumah sakit sudah banyak terjadi di Indonesia. Mulai dari adanya kelalaian tenaga kesehatan dalam keselamatan pasien, malpraktik, dan tindakan kriminal yang lainnya. Sebagai tenaga kesehatan harus menerapkan budaya keselamatan pada pasien dalam pengembangan keselamatan pasien. Dapat dikatakan dengan lebih mudah yaitu keselamatan pasien rumah sakit merupakan suatu hal yang berguna untuk mencegah kejadian yang tidak diinginkan, apabila tidak dapat dicegah diupayakan agar tidak terulang di masa yang akan datang, melalui upaya belajar dari kesalahan yang lama.
\end{abstract}

Kata Kunci : budaya keselamatan pasien, keselamatan pasien, perawat, pasien.

\section{Latar Belakang}

Tidak selalu pelayanan medis yang diberikan tenaga kesehatan dan tenaga keperawatan dapat memberikan hasil yang maksimal. Masih ada beberapa tenaga kesehatan melakukan kesalahan yang biasa disebut malpraktik. Karna maraknya kasus malpraktik di bidang kesehatan budaya keselamatan pasien harus di aplikasikan.

Keselamatan pasien adalah inti dari pelayanan kesehatan. Untuk mencapainya, diperlukan komitmen yang kuat dari individu maupun antar anggota atau tim, Kombinasi dari berbagai bidang di rumah sakit, dengan cara bersama-sama 
menghasilkan sebuah situasi yang berisiko tinggi. Agar bisa memahami risiko dari hal yang kompleks di pelayanan kesehatan.

Rumah sakit dituntut untuk mampu mengelola kegiatannya dengan mengutamakan pada tanggung jawab para profesi professional di bidang kesehatan, khususnya tenaga medis dan tenaga keperawatan dalam menjalankan tugas dan kewenangannya diperlukan penerapan budaya keselamatan pasien seperti keterbukaan informasi antara sesama tenaga kesehatan/staff (budaya keterbukaan), lemahnya penanganan dan observasi pasien (budaya keadilan), dan kerja sama tim dalam pelaporan masalah yang dilakukan untuk mengetahui serta menangani kesalahan sehingga dapat dijadikan pelajaran di masa yang akan datang agar tidak terulang(budaya pelaporan) dan diperlukan informasi tentang masalah kasus error dan nearmissed yang pernah dan kemungkinan dapat terjadi.

Dengan itu kita dapat belajar untuk menutup kesenjangan yang ada, mengurangi morbiditas dan mortalitas untuk mencapai mutu pelayanan yang diharapkan (WHO Patient Safety Curiculum, 2011)

\section{Metode}

Metode yang digunakan dalam kajian ini adalah Literature review, dengan menganalisis, eksplorasi beberapa tesis , jurnal, text book, maupun e-book yang releven dengan kajian dan berfokus pada budaya keselamatan pasien di rumah sakit. E-journal yang digunakan pada literature review ini didapatkan dengan memuat Pubmed, dan Google Scholar dengan memasukkan kata kunci "patient safety culture in hospitals", "Safety Culture", "Patient Safety"

\section{Hasil}

Berdasarkan hasil referensi literature didapatkan pentingnya perawat menerapkan budaya keselamatan pasien di rumah sakit. Dalam literature review yang telah dilakukan dari beberapa sumber, kajian atau penulisan ini mendapatkan hasil yaitu beberapa pelayanan kesehatan tidak berani untuk melaporkan kesalahan yang telah dilakukan dan melaporkan 
kejadian yang tidak diharapkan, karna masih bertanggapan bahwa organisasi tersebut akan disalahkan dan dianggap tidak kompeten, maka budaya keselamatan pasien sangat penting diterapkan di rumah sakit. Hal ini akan menghasilkan pelayanan yang dapat memuaskan pasien terkait pelayanan dan peningkatan kualitas rumah sakit.

\section{Pembahasan}

Rumah sakit merupakan sebuah organisasi di bidang kesehatan yang sangat penting dan dituntut untuk memberikan pelayanan yang bertanggung jawab, serta professional di bidang kesehatan yang bertujuan untuk meningkatkan kualitas kesehatan masyarakat yang optimal.

Namun, tak selamanya tenaga medis dan tenaga keperawatan selalu memberikan hasil yang diharapkan. Tenaga medis dan tenaga keperawatan yang melakukan kelalaian biasa dikenal dengan malpraktik, karna maraknya kasus malpraktik ini maka sangat penting diterapkan budaya keselamatan pasien.
Perawat merupakan tenaga kesehatan

yang melakukan kolaborasi dengan tenaga kesehatan lain. Sebagai perawat yang melakukan tugasnya untuk memberikan asuhan keperawatan sesuai dengan kode etik keperawatan, serta sesuai standar operasional prosedur (SOP) perawat sangat berperan penting dan memiliki tamggung jawab yang sangat besar di rumah sakit terhadap keselamatan masyarakat. Perawat dituntut untuk memberikan pelayanan yang berkualitas sesuai standar kompetensi serta tanggung jawab etika dan moral yang baik.

Perawat juga harus memiliki pengetahuan mengenai kode etik dan hukum kesehatan. Ketika perawat sudah memiliki pengetahuan perihal kode etik dan hukum kesehatan, perawat akan memberikan kinerja yang baik, dan dapat mencapai kinerja yang bertanggung jawab dan professional. Perawat dapat mendapatkan pengetahuan tersebut dari berbagai cara, seperti membaca buku mengenai hukum kesehatan, mengikuti pelatihan atau seminar, atau melalui teman sejawat atau satu profesinya. 
Untuk mencapai keselamatan pasien di rumah sakit diperlukan untuk melakukan perubahan budaya mengenai keselamatan pasien di rumah sakit. Budaya keselamatan sangat penting diaplikasikan karena dengan adanya keyakinan dan nilai yang berkaitan dengan keselamatan pasien, hal tersebut akan dapat mengubah perspektif staff kesehatan atau staff keperawatan mengenai pentingnya melakukan dan mendukung keselamatan pasien. Tidak hanya pada staff kesehatan dan staff keperawatan, pengaplikasian budaya keselamatan pasien sangat berkaitan dengan peran aktif dari manajer dalam melakukan tindakan dan mendukung proses budaya keselamatan pasien.

Namun masih banyak staff kesehatan atau staff keperawatan yang menganggap bahwa peran dari seorang manajer atau supervisor mengenai nilai- nilai keselamatan masih kurang maksimal dan kurang aktif, hal ini akan membuat perubahan nilai- nilai budaya keselamatan pasien tidak tercapai sesuai dengan yang diharapkan. Budaya keselamatan pasien akan berjalan dengan baik, jika manajer/supervisor ikut andil dalam perubahan nilai-nilai keselamatan pasien.

Menurut Peraturan Menteri Kesehatan No. 11 Tahun 2017, Keselamatan pasien merupakan suatu sistem Yang dapat membuat pasien aman. Upaya yang dilakukan meliputi, identifikasi dan pengelolaan risiko pasien, asesmen resiko, kemampuan belajar dari insiden yang sudah pernah terjadi, dan implementasi solusi yang meminimalkan timbulnya resiko dan pencegahan terjadinya cedera yang dikarenakan oleh kelalaian suatu tindaka atau tidak mengambil tindakan yang semestinya dilakukan.

Menurut Kemenkes tahun 2017, untuk mencapai keselamatan pasien, staff kesehatan atau staff keperawatan diharuskan untuk melakukan standar keselamatan pasien, yaitu :

1. Pengetahuan bagi staff tentang keselamatan pasien.

2. Komunikasi yang ada pada staff kesehatan terhadap pasien. 
3. Pendidikan untuk pasien dan keluarga.

4. Hak pasien.

5. Metode peningkatan kinerja untuk melakukan evaluasi.

6. Keselamatan pasien yang persisten atau berkesinambungan

7. Peran kepemimpinan dalam peningkatan keselamatan pasien.

Rumah sakit akan memiliki budaya keselamatan pasien, jika mengaplikasikan beberapa budaya ini, yaitu :

\section{Budaya Pelaporan}

Budaya pelaporan atau reporting culture dalam menerapkan budaya keselamatan pasien. Perawat diharuskan untuk melaporkan jika mengalami kejadian atau kesalahan yang tidak disengaja. Jika terjadinya kejadian yang dimana berisiko dan berpotensi mengakibatkan cedera dari kejadian tidak diharapkan

Melaporkan adanya insiden atau kejadian keselamatan pasien masih jarang terapkan Hal ini karenakan para staff kesehatan atau staff keperawatan takut diberikan hukuman karena melakukan kesalahan pada asuhan keperawatan yang ia berikan.

2. Respon non-punitve (Respon Tidak Menghukum jika terjadi Kesalahan)

Rumah sakit harus mampu menciptakan lingkungan yang tidak menghukum, yang bertujuan agar staff kesehatan atau staff keperawatan tidak takut saat melaporkan kejadian yang telah dilakukan.

Sebagaimana diatur dalam Peraturan Kementerian Kesehatan Republik Indonesia No. 755/Menkes/Per/IV/2011, Mengenai pelaksanaan komite medis di rumah sakit bahwa dilakukan dengan memprioritaskan semua staf untuk menghilangkan blaming (menyalahkan), naming (menyebut atau mencari siapa yang salah), dan shaming (mempermalukan atau mengakui kesalahan) 
3. Adanya dukungan dari manajer/ atasan

Manajer atau supervisor juga harus ikut serta dalam peningkatan keselamatan. Manajer berperan dalam mendukung proses budaya keselamatan pasien, dan dapat mempertimbangkan saran staff kesehatan dan staff keperawatan untuk peningkatan keselamatan pasien.

4. Kerjasama

Kerjasama merupakan indikator yang paling utama dari budaya keselamatan pasien. Dalam melaksanakan asuhan keperawatan kepada pasien, perawat akan selalu membutuhkan bantuan dari teman sejawat atau teman seprofessi maupun tenaga kesehatan yang lainnya. Bentuk kerjasama seperti berupa perawat satu saling membantu pekerjaan ketika perawat lain dihadapkan pada tugas yang sangat banyak dan membutuhkan penyelesaian yang sesegera mungkin.

\section{Penutup}

\section{Kesimpulan}

Dari hasil kajian yang saya kerjakan mengenai pentingnya perawat menerapkan budaya keselamatan pasien di rumah sakit yaitu staff kesehatan atau staff keperawatan sangat penting untuk menerapkan budaya keselamatan pasien yang bertujuan untuk mencegah adanya kejadian yang tidak diinginkan dan berpotensi menyakiti atau cidera pada pasien.

Untuk

mendapatkan informasi terkait keselamatan pasien perawat bisa mendapatkan pengetahuan tersebut dari seminar, buku yang berkaitan dengan hokum kesehatan dan keselamatan pasien, serta dengan cara sharing dengan teman satu profesi atau teman sejawat. Keselamatan pasien dapat dilakukan jika menerapkan budaya keselamatan pasien seperti budaya pelaporan ( Reporting culture), respon tidak menghukum, kerjasama antar profesi dan tenaga kerja lain serta adanya dukungan dari manajer atau supervisor. 


\section{Daftar Pustaka}

Arini,T., Budaya Keselamatan Psien Berbasis Pemberdayaan Struktural Dengan Kepuasan Kerja Perawat. Tesis Fakultas Keperawatan. Universitas Airlangga, Surabaya

Depkes; Peraturan Menteri Kesehatan Republik Indonesia Nomor 755/Menkes/Per/Iv/2011 Tentang Penyelenggaraan Komite Medik Di Rumah Sakit

Hanifa, N.D. Respati, T. Susanti, Y. (2017). Hubungan Pengetahuan dengan Upaya Penerapan K3 pada Perawat. Bandung Meeting on Global Medicine \& Health (BaMGMH). 1(1). 144-149.

Herawati,T.Y. (2015). Budaya Keselamatan Pasien Di Ruang Rawat Inap Rumah Sakit X Kabupaten Jember. Jurnal IKESMA. 11(1). 52-60.

Iriviranty,A., (2015). Analisis Budaya Organisasi dan Budaya Keselamatan Pasien Sebagai Langkah Pengembangan

Keselamatan Pasien di RSIA Budi Kemuliaan Tahun 2014.
Jurnal Administrasi Rumah

Sakit. 1(3). 196-206

Ivana, A. Widjasena, B. Jayanti, S. (2014). Analisa Komitmen Manajemen Rumah Sakit (RS) Terhadap Keselamatan Dan Kesehatan Kerja (K3) Pada RS Prima Medika Pemalang. Jurnal Kesehatan Masyarakat . 2(1). $35-41$.

Lee, N. J., An, J. Y., Song, T. M., Jang, H., \& Park, S. Y. (2014). Psychometric Evaluation of a Patient Safety Competency selfevaluation Tool for Nursing Students. Journal of Nursing Education, 53(10), 550-562

Lee, S. E., Scott, L. D., Dahinten, V. S., Vincent, C., Lopez, K. D., \& Park, C. G. (2017). Safety Culture, Patient Safety, and Quality of Care Outcomes: A Literature Review. Western Journal of Nursing Research

Morello, R. T., Lowthian, J. A., Barker, A. L., McGinnes, R., Dunt, D., \& Brand, C. (2012). Strategies For Improving Patient Safety Culture In Hospitals: A 
Systematic Review. BMJ

Quality \& Safety, 22(1), 11-18.

Mudayana,A.A., (2014). Peran

Aspek Etika Tenaga Medis

dalam Penerapan Budaya

Keselamatan Pasien di Rumah

Sakit. Supplemen Majalah

Kedokteran Andalas, 37 (1). 69-

74

Oktafia, D. (2015). Hubungan Supervisi dan Motivasi Kepala Ruangan dengan Identifikasi Pasien dalam Penerapanpatient Safety oleh Perawat Pelaksana di Ruang Rawat Inap Rumah Sakit Islam Ibnu Sina Padang. Tesis Fakultas Keperawatan. Universitas Andalas. Padang

Simamora, R. H. (2020). Learning of Patient Identification in Patient Safety Programs Through Clinical Preceptor Models. Medico Legal Update, 20(3), 553-556 